\title{
Overexpression of four MiTFL1 genes from mango delays the flowering time in transgenic Arabidopsis
}

\author{
Yi-Han Wang ${ }^{\dagger}$, Xin-Hua He ${ }^{\dagger}$, Hai-Xia Yu, Xiao Mo, Yan Fan, Zhi-Yi Fan, Xiao-Jie Xie, Yuan Liu and Cong Luo*
}

\begin{abstract}
Background: TERMINAL FLOWER 1 (TFL1) belongs to the phosphatidylethanolamine-binding protein (PEBP) family, which is involved in inflorescence meristem development and represses flowering in several plant species. In the present study, four TFL1 genes were cloned from the mango (Mangifera indica L.) variety 'SiJiMi' and named MiTFL11, MiTFL1-2, MiTFL1-3 and MiTFL1-4.

Results: Sequence analysis showed that the encoded MiTFL1 proteins contained a conserved PEBP domain and belonged to the TFL1 group. Expression analysis showed that the MiTFL1 genes were expressed in not only vegetative organs but also reproductive organs and that the expression levels were related to floral development. Overexpression of the four MiTFL1 genes delayed flowering in transgenic Arabidopsis. Additionally, MiTFL 1-1 and MiTFL1-3 changed the flower morphology in some transgenic plants. Yeast two-hybrid (Y2H) analysis showed that several stress-related proteins interacted with MiTFL1 proteins.

Conclusions: The four MiTFL1 genes exhibited a similar expression pattern, and overexpression in Arabidopsis resulted in delayed flowering. Additionally, MiTFL 1-1 and MiTFL1-3 overexpression affected floral organ development. Furthermore, the MiTFL1 proteins could interact with bHLH and 14-3-3 proteins. These results indicate that the MiTFL1 genes may play an important role in the flowering process in mango.
\end{abstract}

Keywords: Mangifera indica L., MiTFL1 genes, Expression, Function, Protein interactions

\section{Background}

Floral transition is an important stage in the life cycle of higher plants. The process underlying the floral transition from the vegetative to reproductive phase is regulated by complex internal signals and external environmental factors $[1,2]$. Various flowering response pathways, such as the photoperiod, vernalization, gibberellin, autonomous, ambient temperature, and age-related pathways, have been identified in the model plant Arabidopsis thaliana [3]. Numerous genes play essential roles

\footnotetext{
*Correspondence: 22003luocong@163.com

${ }^{\dagger}$ Yi-Han Wang and Xin-Hua He contributed equally to this work.

College of Agriculture, State Key Laboratory for Conservation and Utilization of Subtropical Agro-Bioresources, Guangxi University, Nanning 530004, Guangxi, China
}

in these processes, and the involved interactions specify the meristem fate [4]. CONSTANS (CO) contains a zinc finger structure and CCT domain, which activates the transcription of the FLOWERING LOCUS T (FT) gene by binding to the $F T$ promoter region, and the $F T$ protein moves from the leaf tissue to the stem apex to initiate the transition of the plant from vegetative to reproductive growth $[5,6]$. The FLOWER LOCUS C (FLC) gene plays a central role in vernalization-the induction of plant flowering $[7,8]$-and inhibits flowering by binding to FT, FLOWERING LOCUS $D(F D)$ and SUPPRESSOR OF OVER-EXPRESSION OF CONSTANS1 (SOC1) and inhibiting the expression of these genes [9]. The flower meristem-specific genes $L E A F Y(L F Y)$ and APETALA1 (AP1) directly induce shoot apical meristem

(c) The Author(s). 2021 Open Access This article is licensed under a Creative Commons Attribution 4.0 International License, which permits use, sharing, adaptation, distribution and reproduction in any medium or format, as long as you give appropriate credit to the original author(s) and the source, provide a link to the Creative Commons licence, and indicate if changes were made. The images or other third party material in this article are included in the article's Creative Commons licence, unless indicated otherwise in a credit line to the material. If material is not included in the article's Creative Commons licence and your intended use is not permitted by statutory regulation or exceeds the permitted use, you will need to obtain permission directly from the copyright holder. To view a copy of this licence, visit http://creativecommons.org/licenses/by/4.0/ The Creative Commons Public Domain Dedication waiver (http://creativecommons.org/publicdomain/zero/1.0/) applies to the data made available in this article, unless otherwise stated in a credit line to the data. 
differentiation, which promotes the entry of plants into the flowering stage, and then, these genes are activated by $F T$ or $S O C 1$ [10].

TERMINAL FLOWER 1 (TFL1), which belongs to the phosphatidylethanolamine-binding protein (PEBP) family, was first identified in Arabidopsis [11]. TFL1 and FT are genes with highly homologous sequences but opposite functions. TFL1 encodes proteins with conserved His88 and Asp144 residues and the typical amino acid triad modules EYD, YFG, and END [12]. The FT protein does not have this structure, a critical reason for the opposite functions of these two genes [13]. TFL1 genes, as flowering repressors, determine the timing of the transition of the apical meristem into an inflorescence meristem and the branching pattern of the inflorescence [14]. In Arabidopsis, the AtTFL1 gene not only maintains the infinite growth of the stem apical meristem and inflorescence meristem but is also involved in flower formation [15]. In most fruit trees, the function of TFL1 homologous genes is to delay flowering, similar to the function of AtTFL1. For example, the function of PmTFL1 (from Prunus mume) is to delay flowering, as shown in transformed Arabidopsis [16]. The antagonistic effect between FT and TFL1 exhibits a certain relationship with competition with $F D[17,18]$. The TFL1 gene inhibits the expression of $L F Y$ and $A P 1$, which are downstream of the $F T$ gene, by binding to $F D$ and inhibiting flowering [19]. Additionally, $L F Y$ and $A P 1$ regulate the expression of the TFL1 gene in an opposite manner: $L F Y$ serves as an activator, $A P 1$ is a suppressor, and these two genes form an unclear feedback loop. The flowering of plants depends on the ratio of TFL1 to LFY gene expression. A high ratio maintains the plants in a flowering inhibition period, whereas plants with a low ratio are in the early flowering period [20].

Compared with annual plants, woody fruit trees have a longer juvenile period, which severely affects breeding. Several studies have shown that the overexpression or silencing of flowering-related genes can shorten the juvenile period and promote flowering. For example, the BpMADS4 gene from silver birch is constitutively overexpressed in apple, and transgenic plants exhibit markedly shortened juvenile and flowering periods [21]. PCTFL1-1 and PCTFL1-2 were silenced in European pear using RNAi technology, and the plants showed early flowering traits and a shortened juvenile period [22].

Mango (Mangifera indica L.) is a world-famous woody fruit tree that is widely grown in tropical and subtropical areas. Several environmental factors affect mango flowering, including low temperature, water stress, and carbohydrates. Exogenous spraying of potassium nitrate, paclobutrazol and ethephon can promote flowering, whereas spraying of gibberellin inhibits flowering [23]. The publication of the mango genome has provided valuable information regarding the mining of flowering genes [24]. In recent years, several flowering-regulating genes have been isolated and functionally identified in mango, including the flowering-promoting gene MiSOC1 [25], two MiAP1 genes [26], three MiFT genes [27], and a flowering-suppressing gene $(\mathrm{MiCO})$ [28]. The function of MiTFL1 has not been identified in this plant. In the present study, four MiTFL1 homologous genes, namely, MiTFT1-1, MiTFT1-2, MiTFT1-3 and MiTFT14, were cloned from $M$. indica L. cv. 'SijiMi'. The expression patterns of the four MiTFL1 genes in different tissues and at different flowering development stages were evaluated. MiTFL1 gene overexpression vectors were constructed, and the functions of these genes were determined by transformation in Arabidopsis. Proteins interacting with MiTFL1 proteins were screened through yeast two-hybrid $(\mathrm{Y} 2 \mathrm{H})$ assays. The results suggest that these four MiTFL1 genes inhibit mango flowering.

\section{Results \\ Isolation and sequence analysis of MiTFL1 genes}

Four TFL1 homologous genes were identified from the transcriptome and genomic data of 'SijiMi' mango (unpublished data). We further verified the sequences by RT-PCR and showed that these sequences were consistent with those obtained from the transcriptome data. The four genes were named MiTFL1-1, MiTFL1-2, MiTFL1-3 and MiTFL1-4, and their DNA sequence lengths were $1175 \mathrm{bp}, 1054 \mathrm{bp}, 962 \mathrm{bp}$ and $1299 \mathrm{bp}$, respectively. All four MiTFL1 genes contained four exons and three introns (Fig. 1a). Sequence alignment analysis showed that the length of the first exon differed among the four MiTFL1 genes, while the second and third exons had the same length; the fourth exon was $215 \mathrm{bp}$ in length in all the genes except MiTFL1-2, in which the length was $218 \mathrm{bp}$. The full coding sequences of the four MiTFL1 genes were $516 \mathrm{bp}, 525 \mathrm{bp}, 519 \mathrm{bp}$ and $510 \mathrm{bp}$ and encoded 172 aa, 175 aa, 173 aa and 170 aa, respectively. Amino acid sequence alignment analysis showed that the similarity between MiTFL1-3 and MiTFL1-4 was 90\% higher than that between MiTFL1-1 and MiTFL1-2 at 70\%. The amino acid sequences of the MiTFL1-1, MiTFL1-2, MiTFL1-3, and MiTFL1-4 proteins exhibited 68.9, 69.1, 62.9 and $60.1 \%$ similarity with the sequence of AtTFL1 (NP_196004.1) of Arabidopsis, respectively. Additionally, all the MiTFL1 proteins were identified as TFL1 proteins containing the crucial conserved amino acid residues of TFL1-like proteins (Fig. 1b), namely, histidine at position 85 (H85) and aspartic acid at position 140 (D140).

The PEBP gene family is divided into the TFL1, FT and MFT subfamilies. According to phylogenetic tree analysis (Fig. 2), the MiTFL1-1, MiTFL1-2, MiTFL1-3 and MiTFL1-4 proteins were clustered with the TFL1 


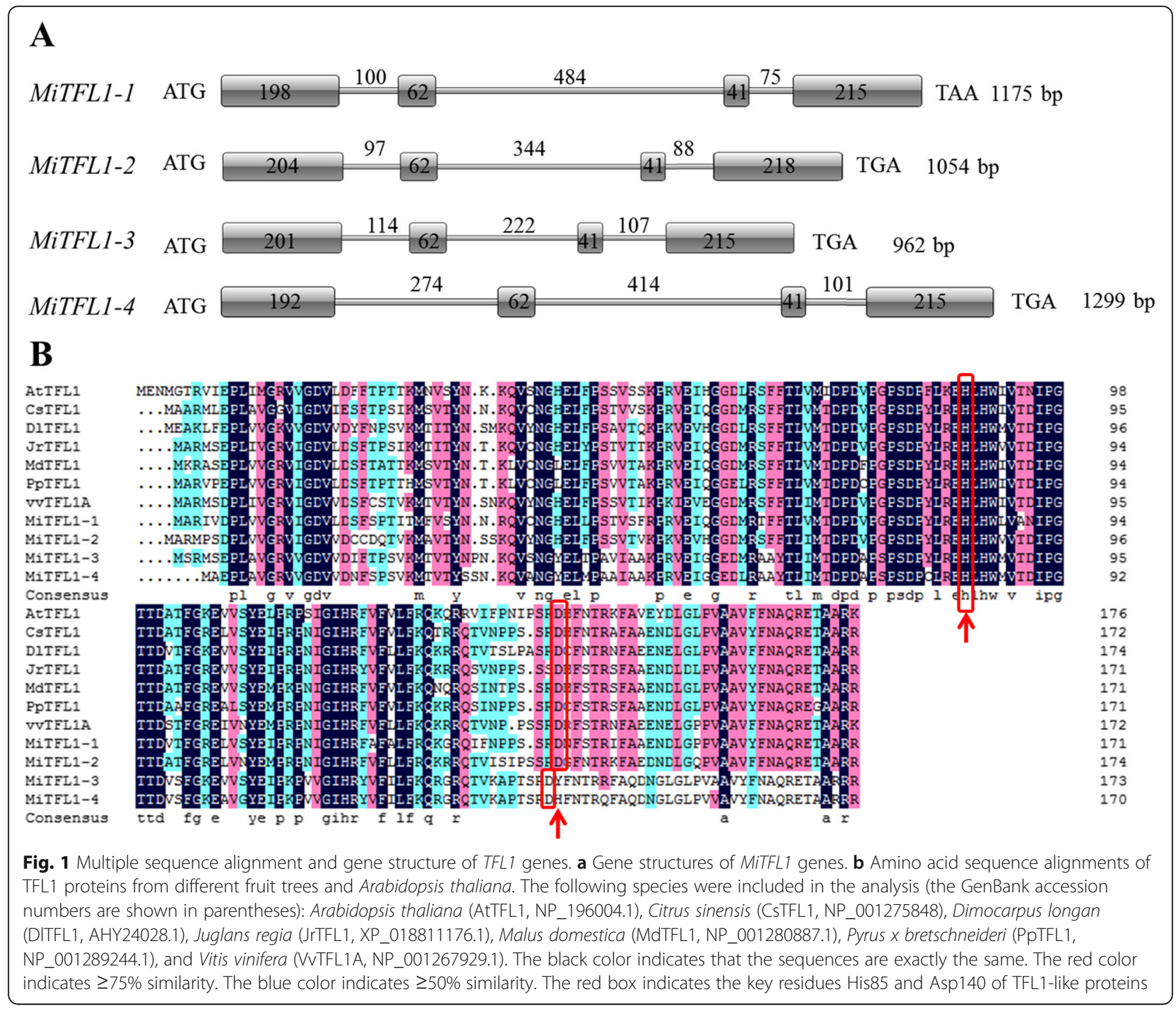

proteins of other species. Among the investigated proteins, the MiTFL1-1 protein is closely related to the TFL1 proteins of apple, pear, apricot, plum, walnut, jujube and other fruit trees of Rutaceae and rose plants. The MiTFL1-2 protein is closely related to the TFL1 proteins of longan and grape and the CEN proteins of apple and cocoa. The MiTFL1-3 and MiTFL1-4 proteins are clustered together and closely related to the PvCEN protein of pistachio.

\section{Expression analysis of MiTFL1 genes}

The expression pattern of MiTFL1 genes in different mango tissues, including flowers, leaves, and stems, was determined by qRT-PCR (Fig. 3A). MiTFL1-1, MiTFL12, MiTFL1-3 and MiTFL1-4 were expressed in flowers, leaves, and stems. MiTFL1-1 and MiTFL1-4 exhibited higher expression levels in leaves than in other tissues.
MiTFL1-2 was highly expressed in flowers, while MiTFL1-3 was highly expressed in stems.

To explore the expression patterns of the MiTFL1 genes at different flowering development stages of mango, mature leaves of $M$. indica L. cv. 'SijiMi' were collected from the vegetative growth period to the flowering and fruiting period (November 2020-May 2021), and the results from the analysis of these leaves are shown in Fig. 3B. The expression patterns of the MiTFL1-1 and MiTFL1-2 genes were similar. The expression levels of these two genes were significantly higher at the floral induction stage than at other stages. The expression level of the MiTFL1-3 gene was high during vegetative growth, decreased significantly during the floral induction period, and increased significantly during the floral differentiation period. The lowest expression level was found at the flowering stage, and a relatively high expression level in leaves was observed 


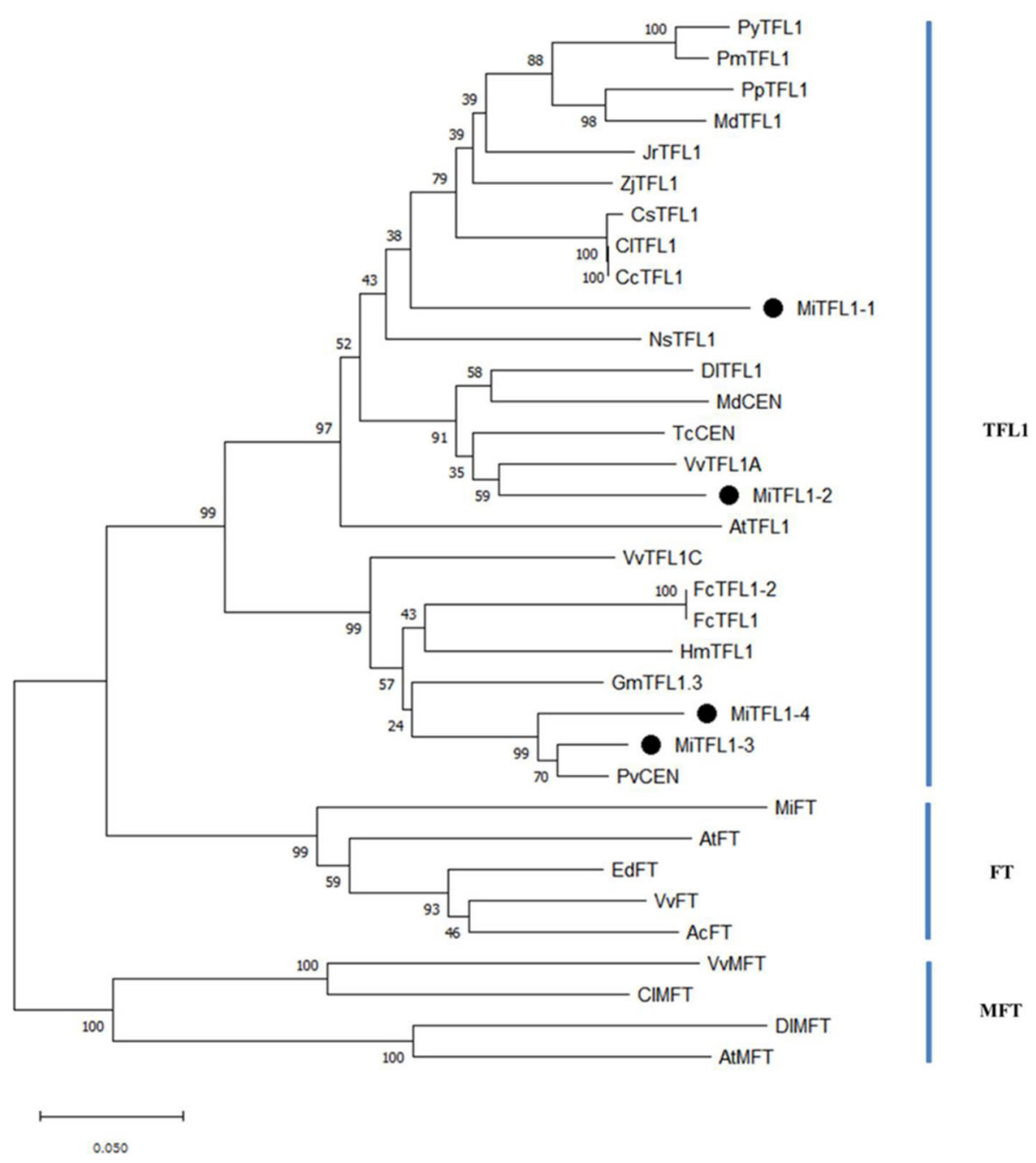

Fig. 2 Phylogenetic tree analysis of PEBP proteins. The following species were included in the analysis (the GenBank accession numbers are shown in parentheses): Arabidopsis thaliana (AtTFL1, NP_196004.1), Citrus sinensis (CsTFL1, NP_001275848), Dimocarpus longan (DITFL1, AHY24028.1), Juglans regia (JrTFL1, XP_018811176.1), Malus domestica (MdTFL1, NP_001280887.1), Pyrus x bretschneideri (PpTFL1, NP_001289244.1), Malus domestica (MdCEN, NP_001280940.1), Pistacia vera (PvCEN protein 1, XP_031269481.1), Theobroma cacao (TcCEN, XP_017973069.1), Hydrangea macrophylla (HmTFL1, MF374628.1), Glycine max (GmTFL1.3, FJ573238.1), Ficus carica (FCTFL1-2, AB746842.1), Citrus clementina (CcTFL1, XP_006430226.1), Citrus limon (CITFL1, AWW25018.1), Ficus carica (FCTFL1, BAX00857.1), Nicotiana sylvestris (NsTFL1, XP_009766168.1), Prunus mume (PmTFL1, AEO72021.1), Prunus yedoensis (PyTFL1, AEO72023.1), Vitis vinifera (VvTFL1A, NP_001267929.1), Vitis vinifera (VvTFL1C, NP_001267933.1), Ziziphus jujube (ZjTFL1, XP_015898753.1), Actinidia chinensis (AcFT, AJA40932.1), Arabidopsis thaliana (AtFT, BAA77838.1), Eriobotrya deflexa (EdFT, AMB72867.1), Mangifera indica (MiFT, AGA19021.1), Vitis vinifera (VvFT, NP_001267907.1), Arabidopsis thaliana (AtMFT, OAP13671.1), Citrus limon (CIMFT, AWW25016.1), Dimocarpus longan (DIMFT, AUG98253.1), and Vitis vinifera (VvMFT, NP_001267935.1)

during fruit development. The expression level of MiTFL1-4 first decreased during the floral induction period and then increased, peaking during the floral differentiation period, which was followed by a decrease and eventually stabilization during the fruit development period.

\section{Subcellular localization of MiTFL1 proteins}

To examine the subcellular localization of MiTFL1 proteins, 35S::GFP-MiTFL1-1， 35S::GFP-MiTFL1-2， 35S:: GFP-MiTFL1-3, 35S::GFP- MiTFL1-4 and 35S::GFPP1300 were separately transformed into onion epidermal cells (Fig. 4). The fluorescence signal of the empty vector 35S::GFP-P1300 was observed in the entire cell. The 35S:: GFP-MiTFL1-1, 35S::GFP-MiTFL1-2, 35S::GFP-MiTFL13 , and 35S::GFP-MiTFL1-4 fusion proteins were visible in only the nucleus and were stained with DAPI.

\section{Phenotypic analysis of MiTFL1 overexpression in Arabidopsis thaliana} MiTFL1 genes delay flowering in Arabidopsis thaliana To explore the function of MiTFL1-1, MiTFL1-2, MiTFL1-3 and MiTFL1-4 in the flowering process of 


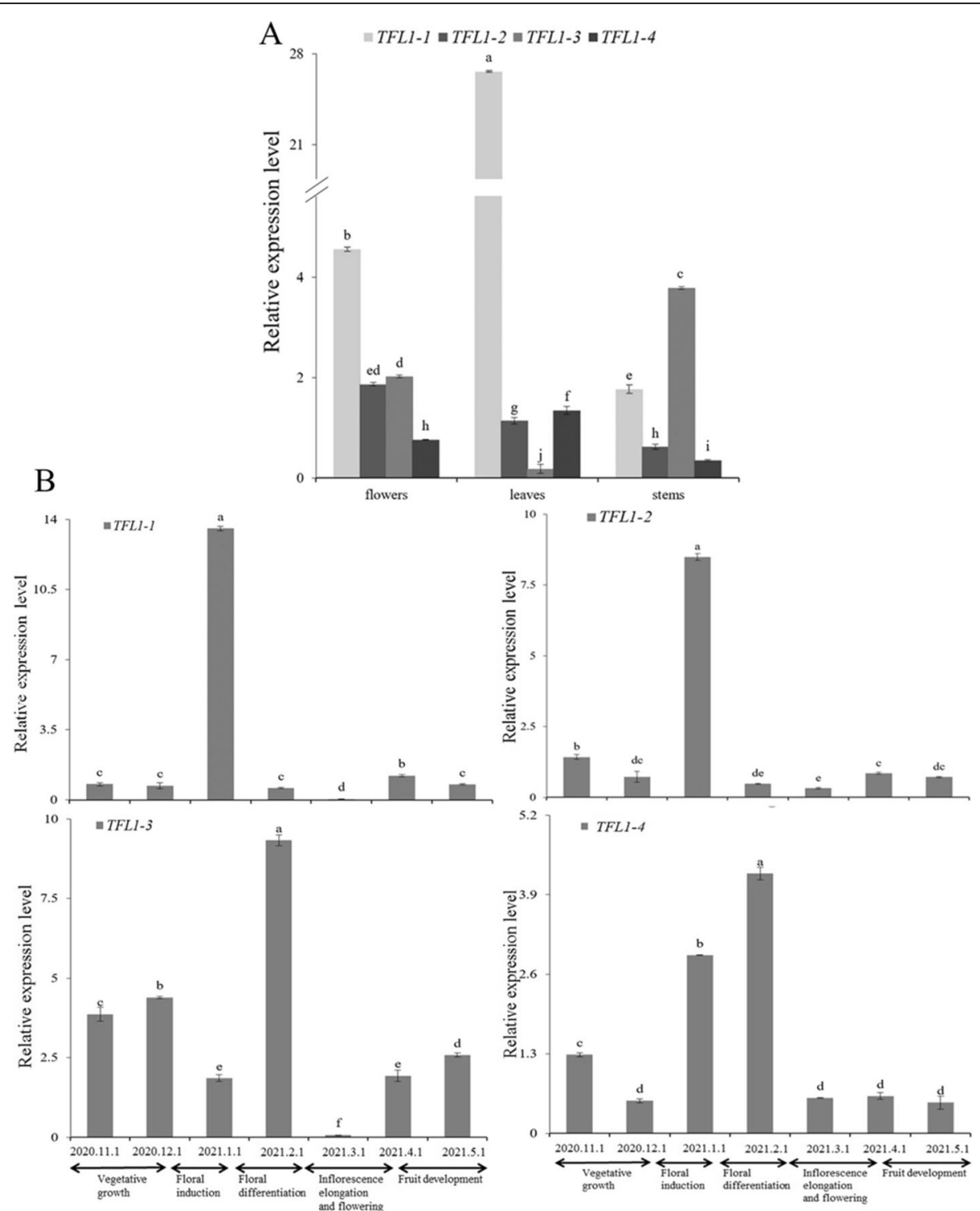

Fig. 3 qRT-PCR analysis of the expression profiles of MiTFL1 genes in mango. A: Expression patterns in different tissues. B: Expression patterns in different flowering developmental stages. The significance of the differences among the samples was assessed by Student's t-test $(P<0.05)$. A Expression pattern of MiTFL1 genes in various tissues (flowers, leaves, and stems). B Expression pattern of MiTFL1 genes in mature leaves over time

mango, individual overexpression vectors of pBI121MiTFL1 were constructed and transferred separately into WT A. thaliana. Phenotypic observations of T3generation homozygous plants were conducted, and WT and pBI121 empty vector-expressing Arabidopsis served as controls.

Four independent lines with MiTFL1-1 overexpression (OE-1\#13, OE-1\#22, OE-1\#25 and OE-1\#29) and three independent lines with MiTFL1-2 overexpression (OE$2 \# 24$, OE-2\#45 and OE-2\#55) were selected for functional analysis. Semiquantitative RT-PCR analysis showed that MiTFL1-1 and MiTFL1-2 were abundantly expressed in the transgenic lines but absent in the empty vector-expressing transgenic or WT plants (Fig. 5A1 and B1). All the independent lines of MiTFL1-1 and MiTFL1-2 showed delayed bolting and flowering: these processes occurred at 28.7-32.5 and 33.3-42.2 days, respectively, in these lines and at 24.9-25.3 and 28.5-28.8 days, respectively, in the control plants (Fig. 5A and B and Table 1). All the transformant lines with MiTFL1-1 and MiTFL1-2 showed normal bolting similar to that observed in the WT plants. Additionally, compared with the heights of the WT plants, those of the MiTFL1-1 and MiTFL1-2 plants were significantly increased, and the rosette leaves were not significantly affected except in OE-1\#13, OE-1\#29 and OE-2\#45 (Table 1). 


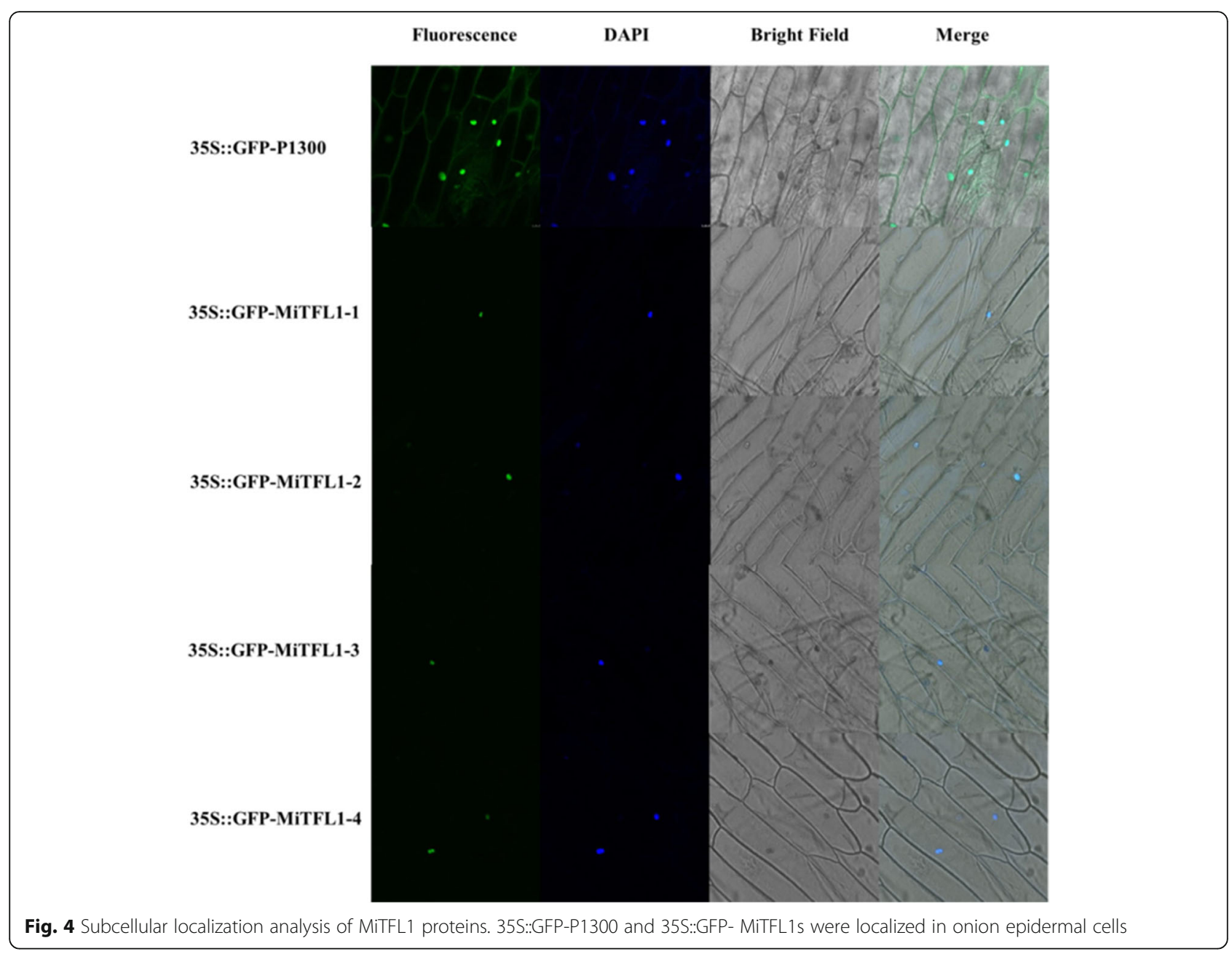

Three independent MiTFL1-3 overexpression (OE3\#19, OE-3\#23 and OE-3\#42) and MiTFL1-4 overexpression (OE-4\#24, OE-4\#45 and OE-4\#55) lines were selected for functional analysis. Semiquantitative RT-PCR analysis demonstrated that MiTFL1-3 and MiTFL1-4 were abundantly expressed in the transgenic lines but absent in WT and pBI121 transgenic Arabidopsis plants (Fig. 6A1 and B1). The bolting time of the MiTFL1-3-overexpressing and MiTFL1-4overexpressing transgenic plants was significantly delayed compared with that of the WT and pBI121 lines under long-day (LD) conditions (Fig. 6a and b and Table 2). The inhibitory effect of MiTFL1-4 on flowering was weaker than those of the other three MiTFL1 genes. The plant heights of some MiTFL1-3 and MiTFL1-4 transgenic lines showed significant differences, but the heights of some of the plants did not significantly differ from those of the control lines. The rosette leaves were not significantly affected in any of the plants (Table 2).

\section{MiTFL1-1 and MiTFL1-3 affect the flower phenotype in Arabidopsis}

The MiTFL1-1-overexpressing (Fig. 7b) and MiTFL1-3overexpressing transgenic lines (Fig. 7c) exhibited similar abnormal phenotypes to those of the WT lines (Fig. 7a). In the transgenic plants, some carpels developed into new inflorescences (Fig. 7B-a and C-a), and some flower structures lacked petals (Fig. 7B-b and C-b), in contrast with the results obtained for the WT plants (Fig. 7A-a and A-b). Two types of silique variations were found in the transgenic plants compared with the WT plants (Fig. 7A-b, A-c): in some siliques, the fruit stalk continued to lengthen from the flower during formation (Fig. 7B-c and C-c); in other siliques, the fruit stalk exhibited curved growth, and the siliques were shorter (Fig. 7B-c and C-c) than those of the WT plants. Additionally, the inflorescences of the transgenic plants were significantly different from those of the WT plants because of the variations in flower morphology (Fig. 7A-d, B-e and C-e). Furthermore, whorled leaves grew on the lateral branches of transgenic Arabidopsis thaliana but not in the control plants (Fig. 7A-e, B-f and C-f). 


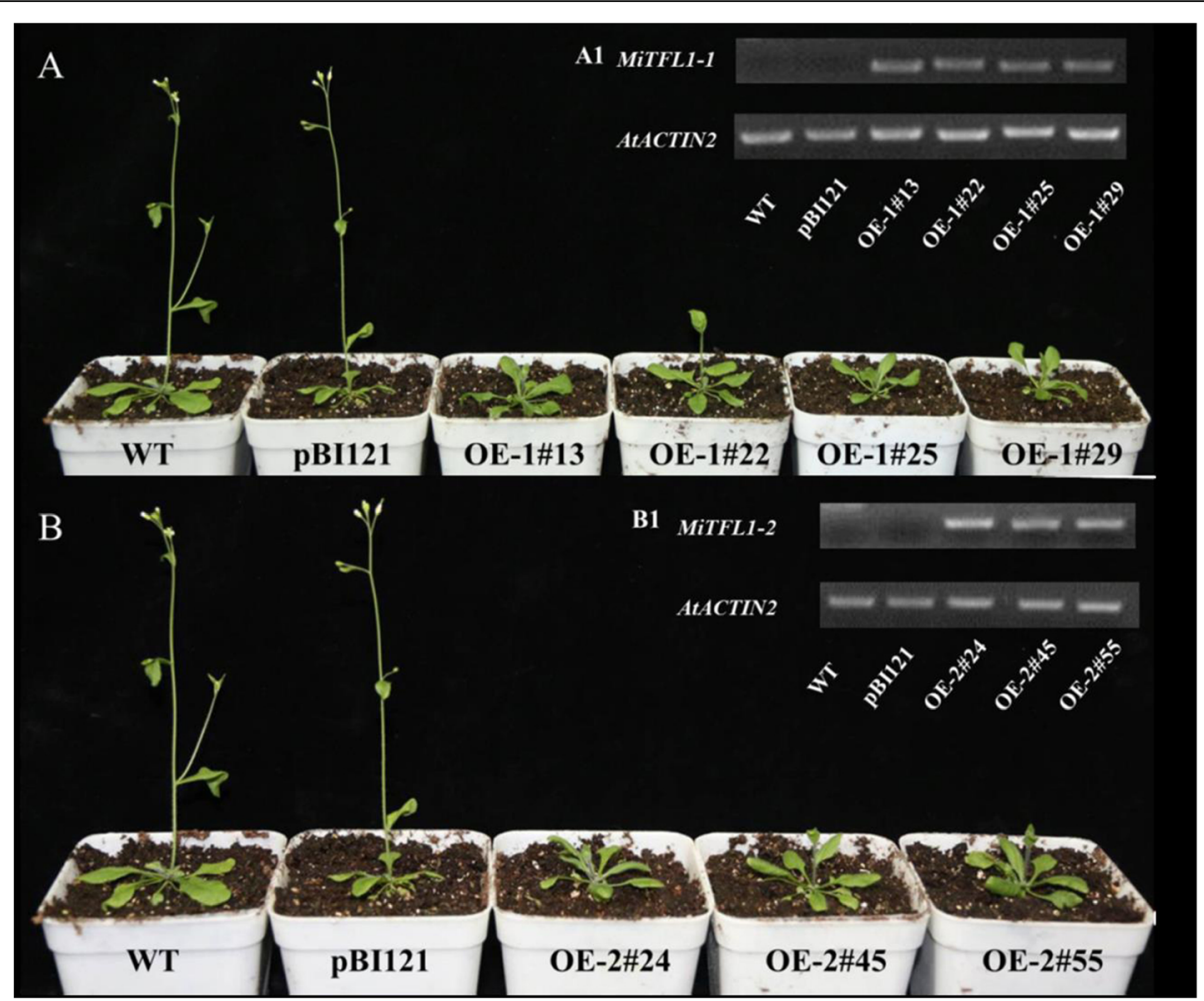

Fig. 5 Phenotype of transgenic Arabidopsis lines and expression profiles of the transgenes. A Phenotype of MiTFL1-1-overexpressing transgenic lines showing delayed flowering (right) and that of the WT and pBl121 transgenic lines as controls (left) under LD conditions. A1 RT-PCR analysis of MiTFL1-1 in the control and MiTFL1-1 overexpression transgenic lines. B Phenotype of MiTFL1-2 overexpression transgenic lines showing delayed flowering (right) and that of the WT and pBI121 transgenic lines as controls (left) under LD conditions. B1 RT-PCR analysis of MiTFL1-2 in the control and MiTFL1-2-overexpressing transgenic lines. The original data can be viewed in Fig. S1a-b

\section{Expression patterns of endogenous genes in transgenic Arabidopsis expressing MiTFL1 genes}

To determine whether MiTFL1 gene overexpression in transgenic Arabidopsis changed the expression of some flowering-related genes, such as the AtFT, AtFD, and AtAP1 homologs in Arabidopsis, the entire aboveground portion of T3 generation homozygous transgenic $A$. thaliana was collected 30 days after planting and subjected to qRT-PCR analysis (Fig. 8). AtACTIN2 was used as the internal reference gene. A similar expression pattern was found for the AtFT, AtFD, and AtAP1 transcripts in Arabidopsis after overexpressing each of the four MiTFL1 genes (Fig. 8a-d). The expression levels of the AtFT and AtAP1 genes were significantly lower in all

Table 1 Flowering phenotype analysis of WT, pBI121, MiTFL1-1-overexpressing (OE-1) and MiTFL1-2-overexpressing (OE-2) transgenic plants

\begin{tabular}{llllll}
\hline ID & Number & Days to bolting (d) & Days to flowering (d) & No. of rosette leaves & Plant height (cm) \\
\hline WT & 13 & $25.3 \pm 0.1$ & $28.8 \pm 0.2$ & $8.1 \pm 0.2$ & $24.1 \pm 0.8$ \\
PBI121 & 13 & $24.9 \pm 0.2$ & $28.5 \pm 0.3$ & $7.9 \pm 0.2$ & $24.7 \pm 0.4$ \\
OE-1\#13 & 10 & $32.3 \pm 0.5^{*}$ & $42.2 \pm 1.1^{*}$ & $8.7 \pm 0.2^{*}$ & $35.7 \pm 1.2^{*}$ \\
OE-1\#22 & 8 & $28.8 \pm 0.4^{*}$ & $33.3 \pm 0.4^{*}$ & $8.1 \pm 0.3$ & $31.9 \pm 1^{*}$ \\
OE-1\#25 & 9 & $29.1 \pm 0.6^{*}$ & $33.9 \pm 0.5^{*}$ & $8.4 \pm 0.3$ & $30.1 \pm 0.5^{*}$ \\
OE-1\#29 & 9 & $28.7 \pm 0.4^{*}$ & $33.4 \pm 0.6^{*}$ & $8.9 \pm 0.3^{*}$ & $29.6 \pm 0.6^{*}$ \\
OE-2\#24 & 12 & $31.6 \pm 0.5^{*}$ & $37.2 \pm 0.7^{*}$ & $8.6 \pm 0.3$ & $36.1 \pm 1.2^{*}$ \\
OE-2\#45 & 10 & $32.5 \pm 0.3^{*}$ & $38.8 \pm 1.2^{*}$ & $8.8 \pm 0.3^{*}$ & $38.2 \pm 1.5^{*}$ \\
OE-2\#55 & 12 & $29.7 \pm 0.3^{*}$ & $34.6 \pm 0.5^{*}$ & $8.5 \pm 0.3$ & $31.8 \pm 1.0^{*}$ \\
\hline
\end{tabular}

The analysis was performed using four MiTFL1-1-overexpressing and three MiTFL1-2-overexpressing independent transgenic lines. The bolting time and rosette leaves were measured when the bolting height was $0.5-1 \mathrm{~cm}$. The flowering time was considered the time when the first flowers opened. The plant height was measured 15 days after flowering. The error bars represent \pm SD. The asterisks indicate significant differences (Duncan's test: $* P<0.05$ ) 


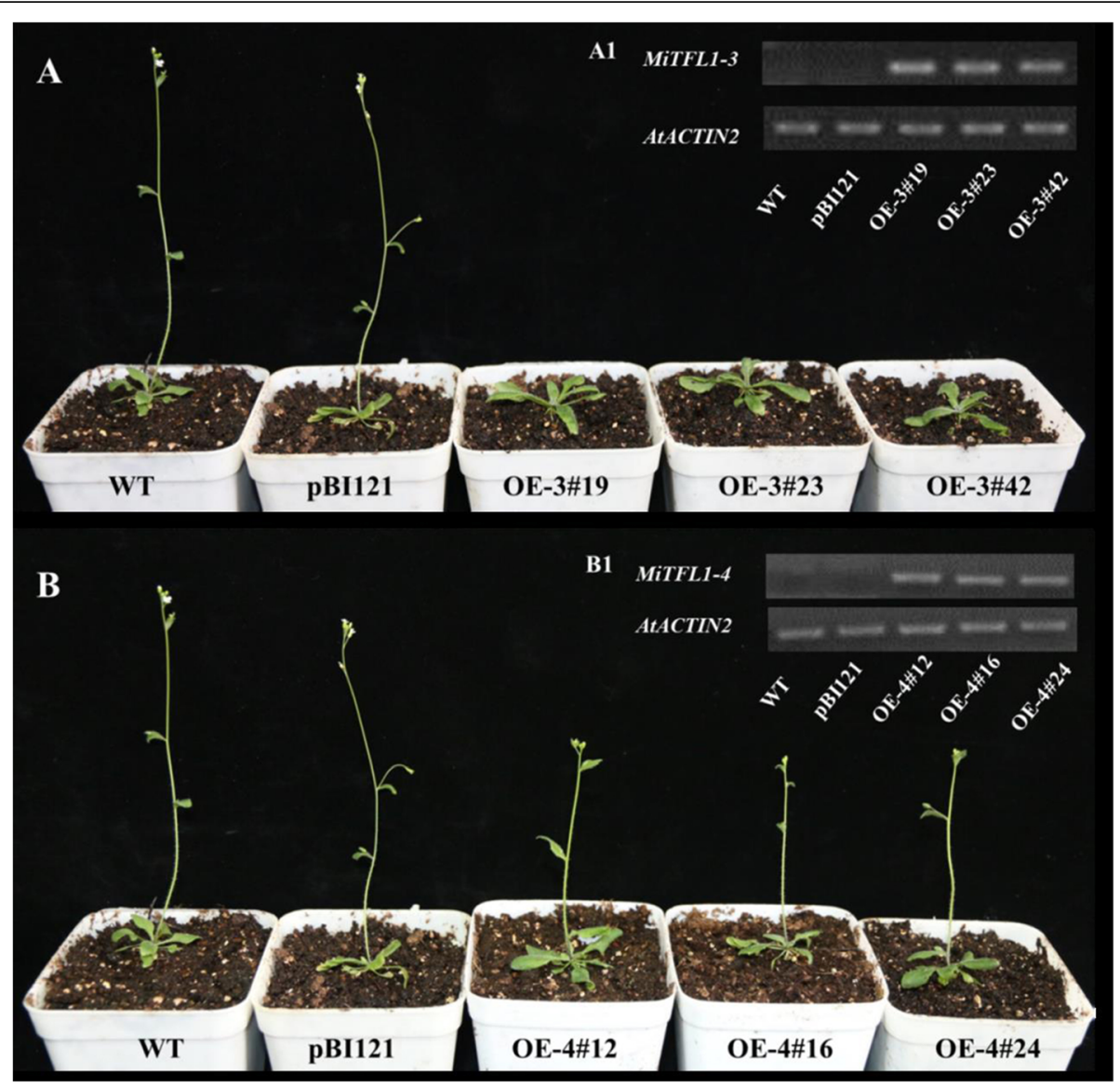

Fig. 6 Phenotype of transgenic Arabidopsis lines and expression profiles of the transgenes. A Phenotype of MiTFL1-3-overexpressing transgenic lines showing delayed flowering (right) and that of WT and pBl121 transgenic lines as controls (left) under LD conditions. A1 RT-PCR analysis of MiTFL1-3 in the control and MiTFL1-3-overexpressing transgenic lines. B Phenotype of the MiTFL1-4-overexpressing transgenic lines, showing delayed flowering (right), and that of the WT and pBI121 transgenic lines as controls (left) under LD conditions. B1 RT-PCR analysis of MiTFL 1-4 in the control and MiTFL1-4-overexpressing transgenic lines. The original data can be viewed in Fig. S1c-d

Table 2 Flowering phenotype analysis of WT, pBI121, MiTFL1-3-overexpressing (OE-3) and MiTFL1-4-overexpressing (OE-4) plants

\begin{tabular}{llllll}
\hline ID & Number & Days to bolting (d) & Days to flowering (d) & No. of rosette leaves & Plant height (cm) \\
\hline WT & 10 & $24.8 \pm 0.3$ & $28.1 \pm 0.3$ & $8.1 \pm 0.2$ & $24 \pm 2.9$ \\
pBI121 & 10 & $24.7 \pm 0.3$ & $27.4 \pm 0.2$ & $8.2 \pm 0.4$ & $25.3 \pm 0.8$ \\
OE-3\#19 & 12 & $37.0 \pm 0.5^{*}$ & $47.3 \pm 0.6^{*}$ & $8.5 \pm 0.2$ & $38.9 \pm 1.1^{*}$ \\
OE-3\#23 & 11 & $30.9 \pm 0.6^{*}$ & $38.9 \pm 1.9^{*}$ & $8.4 \pm 0.3$ & $36.1 \pm 1.2^{*}$ \\
OE-3\#42 & 12 & $30.2 \pm 0.6^{*}$ & $34.7 \pm 0.7^{*}$ & $8.3 \pm 0.2$ & $26.3 \pm 2.0$ \\
OE-4\#12 & 10 & $28.0 \pm 0.7^{*}$ & $31.8 \pm 0.6^{*}$ & $7.6 \pm 0.3$ & $26.9 \pm 0.7$ \\
OE-4\#16 & 10 & $26.8 \pm 0.3^{*}$ & $30.7 \pm 0.3^{*}$ & $8.2 \pm 0.2$ & $26.5 \pm 0.3$ \\
OE-4\#24 & 10 & $29.4 \pm 0.8^{*}$ & $32.9 \pm 0.8^{*}$ & $7.7 \pm 0.3$ & $31.2 \pm 1.0^{*}$ \\
\hline
\end{tabular}

The analysis was performed using three MiTFL1-3-overexpressing and three MiTFL1-4-overexpressing independent transgenic lines. The bolting time and rosette leaves were measured when the bolting height was $0.5-1 \mathrm{~cm}$. The flowering time was considered the time when the first flowers opened. The plant height was measured 15 days after flowering. The error bars represent \pm SD. The asterisks indicate significant differences (Duncan's test: ${ }^{*} P<0.05$ ) 
$\mathbf{A}$
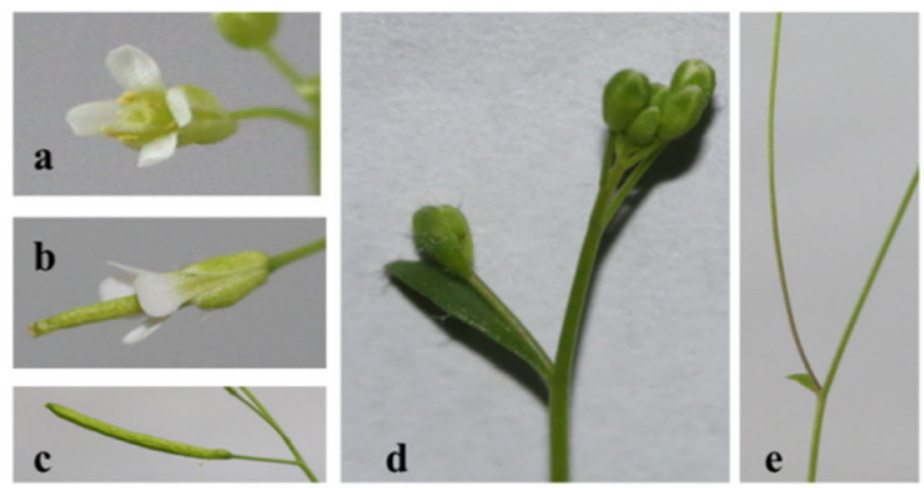

B
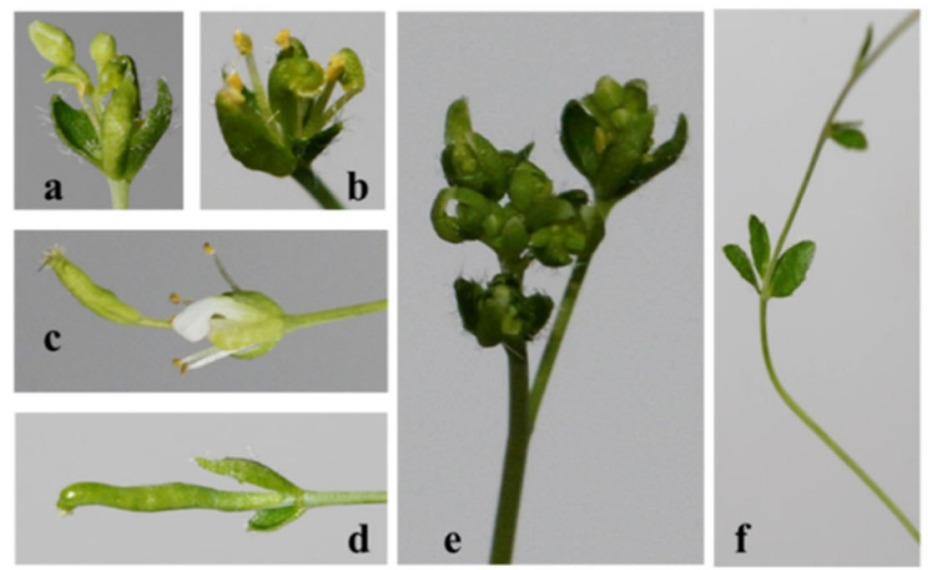

C
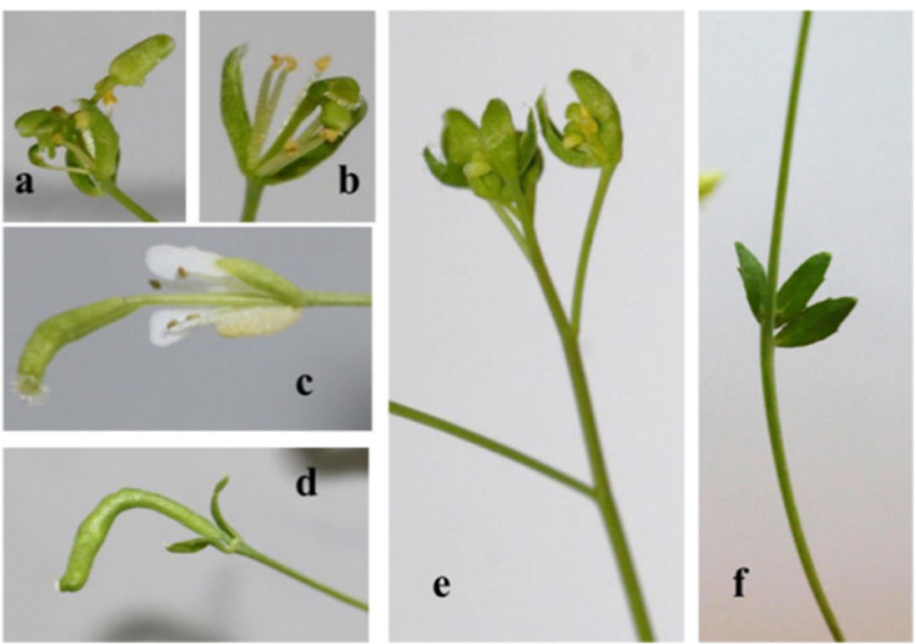

Fig. 7 Photographs of the plant architecture, inflorescence, and floral phenotypes of WT and MiTFL1-1 and MiTFL1-3 transgenic Arabidopsis lines. A Phenotypes of WT Arabidopsis: (a, b) flowers, (c) silique, (d) inflorescence, and ( $f$ ) stem. B Phenotypes of the MiTFL1-1-overexpressing line OE1\#13: (a) altered flower organs and no petals or carpels becoming a new inflorescence; (b) flower lacking petals; (c) a longer pod stalk formed in flowers; (d) pods with curved growth; (e) abnormal inflorescence; and (f) whorled leaves growing on the stem. C Phenotypes of the MiTFL1-3overexpressing line OE-3\#19: (a) altered flower organs and no petals or carpels becoming a new inflorescence; (b) flower lacking petals; (c) a longer pod stalk formed in flowers; (d) pods with curved growth; (e) abnormal inflorescence; and (f) whorled leaves growing on the stem

the MiTFL1-overexpressing transgenic lines than in the WT plants. However, the expression of the AtFD gene was significantly increased in many transgenic lines but not in the MiTFL1-2-overexpressing line OE-2\#45.

\section{Proteins that interact with MiTFL1 proteins}

The $\mathrm{Y} 2 \mathrm{H}$ system was used to screen the proteins interacting with MiTFL1 proteins and verify their interactions. The bait vector pGBKT7-MiTFL1 was constructed 

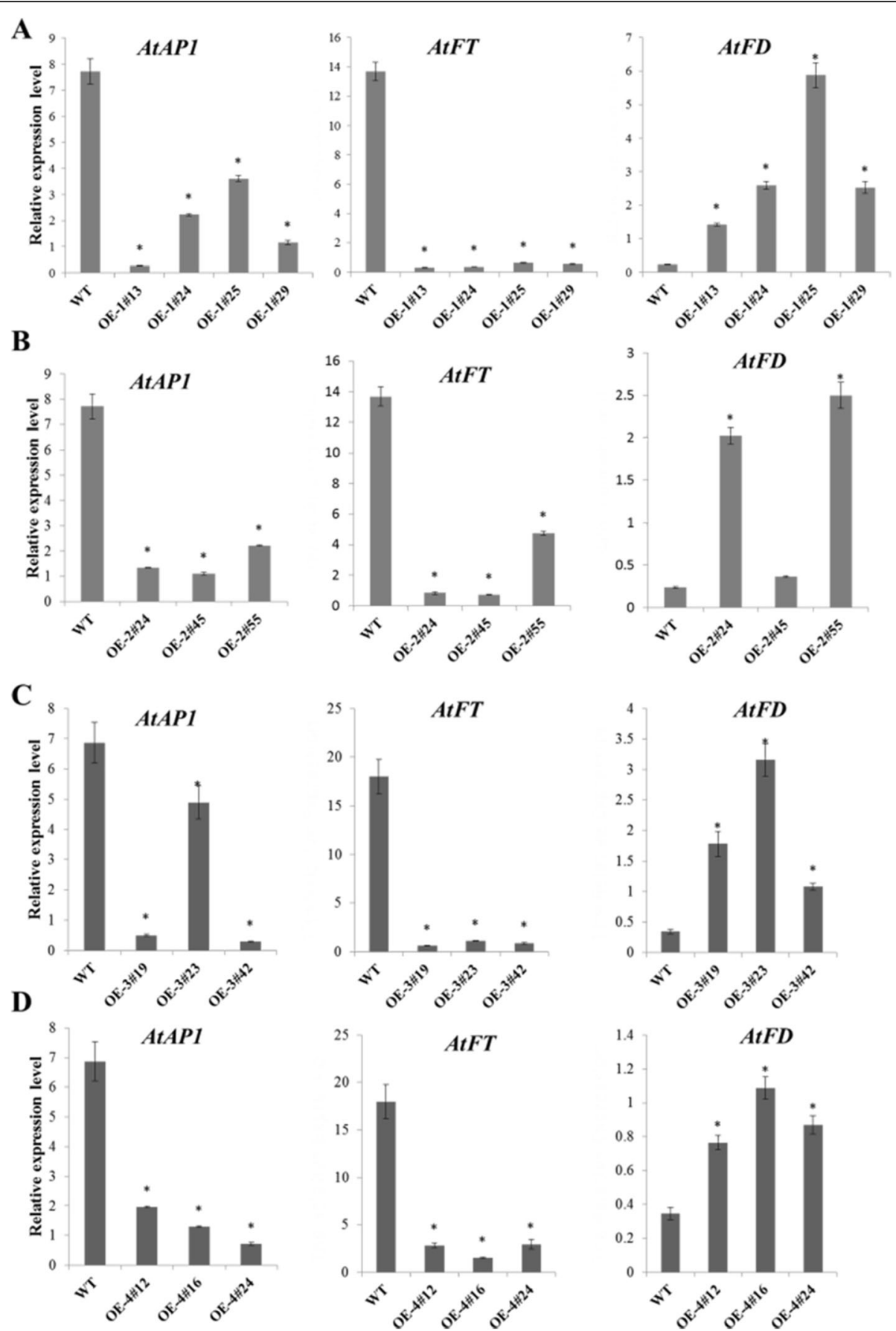

Fig. 8 Expression analyses of flowering-related genes in transgenic Arabidopsis. a-d qRT-PCR analysis of endogenous flowering-related genes, including Arabidopsis AtAP1, AtFT and AtFD, in the MiTFL1-overexpressing and WT lines. The expression level was normalized to that of Arabidopsis AtACTIN2. The data are shown as the means \pm SEs from three biological replicates. The significance of the differences among the samples was determined by Duncan's test $(P<0.05)$

by double enzyme digestion, and no autoactivation or toxicity was detected (shown in Fig. S2). Yeast cells with bait plasmids were combined with the cDNA homogenization library of 'SijiMi' to screen for positive clones. After $\mathrm{Y} 2 \mathrm{H}$ assays, we obtained 9 candidate proteins associated with the MiTFL1-1 protein, 7 with
MiTFL1-2, 6 with MiTFL1-3, and 7 with MiTFL1-4 (Table S1). Three stress- or flowering-related proteins were selected from the candidate proteins for further point-to-point verification on $\mathrm{DDO} / \mathrm{X}$ and $\mathrm{QDO} / \mathrm{X} / \mathrm{A}$ media. The three proteins were basic helix-loop-helix protein 13 (bHLH13), bHLH162 and 14-3-3D, as shown 
in Fig. 9. The cells with the candidate protein bHLH13 in the pGADT7 recombinant vector turned blue and exhibited normal growth on QDO/X/A solid medium, indicating that the protein interacts with MiTFL1-2 and MiTFL1-3 proteins. bHLH162 interacted with MiTFL11, MiTFL1-2 and MiTFL1-4, whereas 14-3-3D interacted with only MiTFL1-1 and MiTFL1-2.

\section{Discussion}

FT and TFL1 encode a pair of flowering regulators belonging to the PEBP family and play critical roles during the switch from vegetative growth to reproductive development [19]. FT and TFL1 share high homology, as demonstrated by their high nucleotide and amino acid sequence identities, but have opposite functions. $F T$ promotes the transition to reproductive development and flowering, whereas TFL1 represses flowering [19, 29]. Our previous study identified three $F T$ genes from mango and further confirmed that all $F T$ genes significantly promoted flowering in the transgenic plants [27]. In the present study, four TFL1 genes were obtained from transcriptomic and genomic data analysis of 'SijiMi' mango (unpublished data) and were named MiTFL1-1, MiTFL1-2, MiTFL1-3 and MiTFL1-4. Sequence analysis showed that the four TFL1 genes of 'SijiMi' mango were highly consistent with the nucleotide sequences of 'Alphonso' (Fig. S3).

Multiple copies of TFL1 homologous genes are also found in other plants, such as two in soybean [30], moso bamboo [13] and loquat [31], three in petunia [32], four in cotton [33] and five in Hevea brasiliensis [34]. In a previous study, only two TFL1 genes, namely, MiTFL1 and MiTFL1a, were found in another mango variety, 'Alphonso', corresponding to MiTFL1-2 and MiTFL1-1, respectively, in the present study [35]. MiTFL1 genes contain four exons and three introns. The nucleotide lengths of the second and third exons were highly consistent among different MiTFL1 genes (Fig. 1a). The critical amino acids His88 and Asp144 of TFL1 proteins were also found in these four MiTFL1 proteins (Fig. 1b). The constructed phylogenetic tree indicated that the four MiTFL1 proteins belong to the TFL1 protein branch. In the tree, MiTFL1-1 and MiTFL1-2 were close to each other, whereas MiTFL1-3 and MiTFL1-4 were also located close to each other (Fig. 2).

The TFL1 gene expression pattern is related to floral development in most fruit trees. Citrus CsTFL1 is expressed only in floral organs [36]. P. mume PmTFL1 is expressed in the leaves, stems, and roots in the juvenile phase, whereas PmTFL1 has been detected only in leaf buds and young leaves at the mature stage [16]. The PpTFL1 gene of peach is mainly expressed in mature young leaves but is not found in mature leaves and flower organs [37]. EjTFL1-1 is mainly expressed in roots and leaf buds but is expressed at low levels in shoots, flower buds and flowers. EjTFL1-2 is mainly expressed in leaf buds, flowers, and fruits and is not expressed in other tissues [31]. In the present study, MiTFL1 genes showed different expression patterns compared to those reported above. Tissue expression

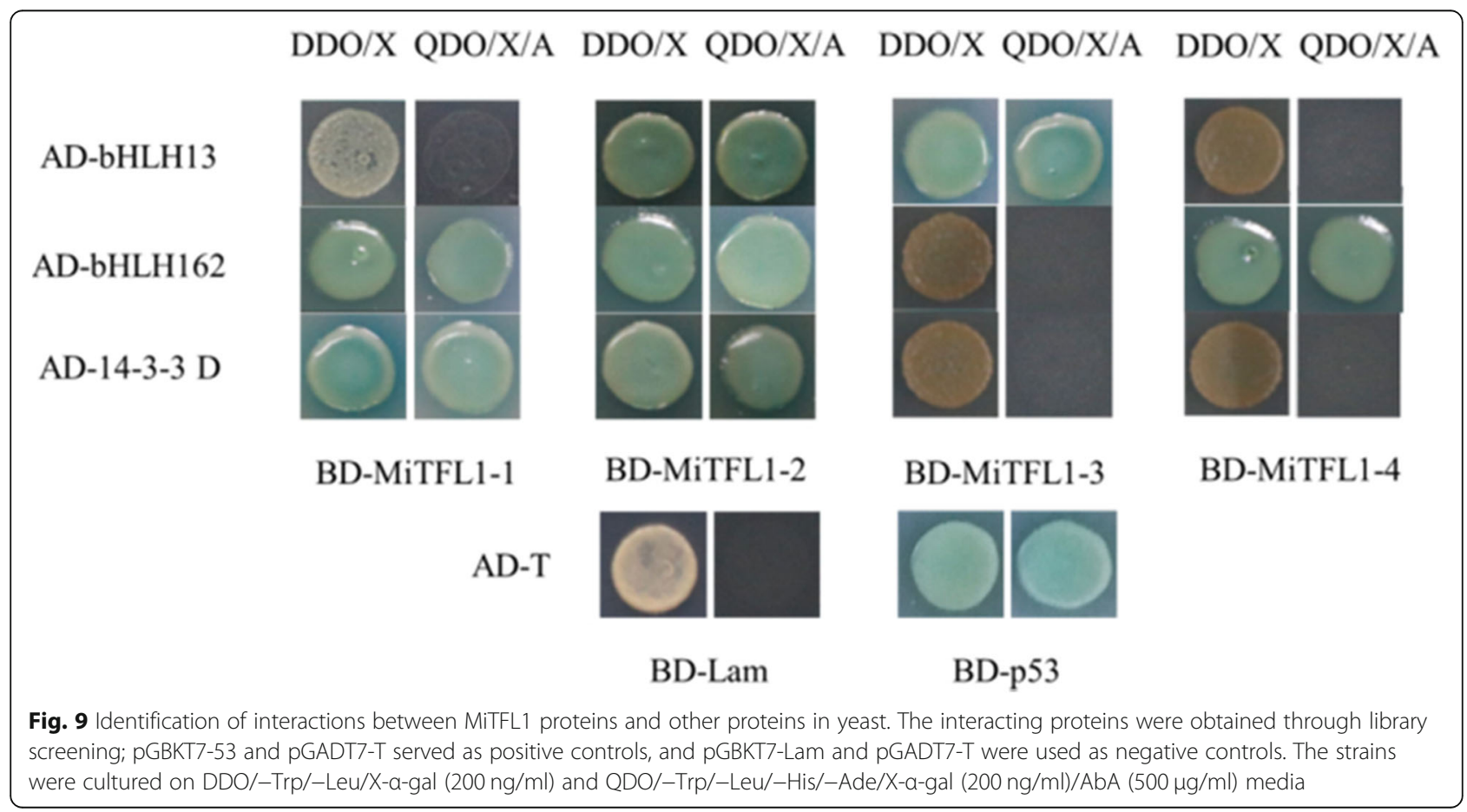


analysis showed that MiTFL1-1, MiTFL1-2, MiTFL1-3 and MiTFL1-4 were expressed in both vegetative and reproductive tissues but differed in expression levels. Our results were similar to those found in other mango varieties, namely, 'Alphonso' and 'Ratna' [35]. These results indicated that the tissue expression pattern of the TFL1 gene was significantly different among different species.

Some studies have shown that the expression pattern of the TFL1 gene is different at different stages of floral development. For example, in pear, apple, and quince, the TFL1-1 and TFL1-2 genes are highly expressed in buds before floral differentiation, and their expression appears to decrease after floral differentiation [38]. In $H$. brasiliensis, HbTFL1-1, HbTFL1-2 and HbTFL1-3 expression increases gradually during inflorescence development, but the expression of HbCEN1 and HbCEN2 continuously decreases over this period [39]. The expression levels of EjTFL1-1 and EjTFL1-2 gradually decrease before floral bud differentiation and start to increase again during the flower-opening period [31]. In the mango variety 'Alphonso', MiTFL1 expression increases during the flowering induction period and subsequently decreases, whereas MiTFL1a expression remains low during the flowering period [35]. In this study, the expression of the MiTFL1 gene in mango was similar to that reported above. MiTFL1-1 and MiTFL1-2 were highly expressed in leaves at the floral induction stage, while MiTFL1-3 and MiTFL1-4 were highly expressed in leaves at the floral differentiation stage.

TFL1 homologous genes have similar functions in many species, and these functions include delaying the flowering time and maintaining the inflorescence meristem through suppression of $A P 1$ and $L F Y$ expression [15]. Overexpression of apple MdTFL1 in Arabidopsis delays flowering time, and inhibition of the expression of the MdTFL1 gene by RNAi technology results in early flowering traits [34, 40]. The Japanese apricot PmTFL1 [16] and five rubber TFL1 genes showed the same function in transgenic Arabidopsis [39]. In the present study, four mango MiTFL1 genes had the same function of delaying flowering time in transgenic Arabidopsis. Moreover, the MiTFL1-1 and MiTFL1-3 transgenic lines exhibited abnormal flower organ phenotypes, such as missing petals, carpel development into a new inflorescence, curved pod growth and seed abortion. These results suggest that MiTFL1-1 and MiTFL1-3 are involved in flower organ development. Similar phenotypes were also found in chrysanthemum CmTFL1c- and Prunus PsTFL1-overexpressing transgenic Arabidopsis lines [41, 42].

Introduction of the exogenous TFL1 gene significantly downregulated the expression levels of the endogenous genes AtFT and AtAP1 in transgenic Arabidopsis, leading to delayed flowering. For example, overexpressing the HKTFL1 gene in Hemerocallis delayed flowering, and the expression levels of AtFT and AtAP1 in transgenic Arabidopsis were decreased compared with those in WT Arabidopsis [43]. The Chrysanthemum morifolium CmTFL1c gene negatively regulates flowering by inhibiting AtFT, AtLFY and AtAP1 expression [42]. Cucumber CsTFL1b also delays flowering in Arabidopsis and decreases and increases the expression levels of AtFT and $A t F D$, respectively [4]. In the present study, we found that four MiTFL1 genes downregulated AtFT and AtAP1 expression but upregulated AtFD expression in transgenic Arabidopsis.

In rice, the TFL1-like protein RICE CENTRORADIALIS (RCN) can directly interact with the 14-3-3 protein [44]. In this study, we also screened some proteins interacting with MiTFL1 using $\mathrm{Y} 2 \mathrm{H}$ assays (Table S1). For example, the 14-3-3D protein was found to interact with MiTFL1-1 and MiTFL1-2, and this result was similar to that found in rice. Two other bHLH proteins were also found to interact with different MiTFL1 proteins and play a role in several processes, including growth, development, and the response to various stresses [45]. Additionally, other proteins that may interact with MiTFL1 proteins have been screened, and they are also involved in the stress response, plant growth and development. However, these interacting proteins must be further tested.

\section{Conclusions}

In the present study, four MiTFL1 genes were identified in mango. These proteins contained both the critical amino acids His88 and Asp144. Expression analysis showed that the MiTFL1 genes exhibited a similar expression pattern: the MiTFL1 genes were expressed in vegetative and reproductive tissues and were highly expressed in mature leaves during the flowering induction period and floral differentiation stage. Overexpression of the four MiTFL1 genes in Arabidopsis resulted in delayed flowering, whereas MiTFL1-1 and MiTFL1-3 overexpression affected floral organ development. $\mathrm{Y} 2 \mathrm{H}$ analysis showed that the MiTFL1 proteins interact with bHLH and 14-3-3 proteins. These results provide preliminary evidence that MiTFL1 genes negatively regulate floral induction in mango, but their interaction mechanisms must be further validated.

\section{Methods}

\section{Plant materials and growth conditions}

The M. indica L. cv. 'SijiMi' plants used in this study were planted in an orchard at Guangxi University, Nanning, Guangxi, China $\left(22^{\circ} 502 \mathrm{~N}, 108^{\circ} 17^{\prime} \mathrm{E}\right)$. For tissue expression analysis, leaves, stems and flowers were collected from 17-year-old trees on 10 March 2021. For seasonal expression analysis, leaves (closer to the terminal bud) were collected once per month from 1 
November 2020 (vegetative period) to 1 May 2021 (fruit development period). All the samples were immediately frozen in liquid nitrogen and stored at $-80^{\circ} \mathrm{C}$. The Arabidopsis ecotype Col-0 was maintained in our laboratory.

\section{Isolation of MiTFL1 genes from mango}

Total RNA was extracted from mango leaves using the RNAprep Pure Plant Kit (TianGen, Beijing, China) according to the manufacturer's instructions. First-strand cDNA was synthesized from $1 \mu \mathrm{g}$ of total RNA using MMLV reverse transcriptase (TaKaRa, Dalian, China) according to the manufacturer's instructions. Genomic DNA was extracted from mango leaves using the CTAB method. Four TFL1 genes were obtained from mango leaves and named MiTFL1-1, MiTFL1-2, MiTFL1-3 and MiTFL1-4. Specific primers (QTFL1-1u/d, QTFL1-2u/d, QTFL1-3u/d, and QTFL1-4u/d; Table S2) were designed to amplify MiTFL1 genes from genomic DNA and cDNA. The polymerase chain reaction (PCR) mixture contained $2.5 \mu \mathrm{l}$ of $10 \times$ PCR buffer (with $\mathrm{MgCl}^{2+}$ ), $0.5 \mu \mathrm{l}$ of $10 \mathrm{mM}$ dNTPs (Sangon Biotech, Shanghai, China), $1 \mu \mathrm{l}$ of each of the upstream and downstream primers $(10 \mu \mathrm{M}), 0.15 \mu \mathrm{l}$ of TransTaq-T DNA polymerase (TianGen), $1 \mu \mathrm{l}$ of genomic DNA (100 ng/ $\mu \mathrm{l})$ or cDNA (100 $\mathrm{ng} / \mu \mathrm{l})$, which served as the templates, and sterile water $(25 \mu \mathrm{l})$. The PCR amplification conditions included an initial denaturation step of $4 \mathrm{~min}$ at $95^{\circ} \mathrm{C} ; 38$ cycles of $95^{\circ} \mathrm{C}$ for $40 \mathrm{~s}, 56^{\circ} \mathrm{C}$ for $50 \mathrm{~s}$, and $72^{\circ} \mathrm{C}$ for $\mathrm{N} \min (N=1$ $\mathrm{min} / \mathrm{kb})$; and a final extension at $72^{\circ} \mathrm{C}$ for $10 \mathrm{~min}$. The amplified fragments were cloned into the pMD18-T vector (Takara) and then sequenced.

\section{Sequence analysis}

Sequence analysis and amino acid prediction were performed using BioXM 2.6 software. IBS version 1.0 was used to generate exon-intron structures. The conserved domains were analyzed using the NCBI BLAST search engine (https://www.ncbi.nlm.nih.gov/Structure/cdd/ wrpsb.cgi). The amino acid sequences of the FT1/TFL1 family were downloaded through BLAST searches of GenBank (http://www.ncbi.nlm.nih.gov/BLAST/). Multiple sequence alignments of TFL1 proteins were analyzed using DNAMAN software. The phylogenetic tree was constructed using the neighbor-joining method in MEGA-X with 1000 bootstrap replicates.

\section{Expression analysis of MiTFL1 genes}

The expression of MiTFL1 genes was detected by quantitative real-time PCR. Total RNA from all the samples was extracted using the RNAprep Pure Plant Kit (TianGen) according to the manufacturer's instructions. Firststrand cDNA was synthesized and used as a template. Gene-specific primers (qTFL1-1u/d, qTFL1-2u/d, qTFL1-3u/d and qTFL1-4u/d; Fig. S4) were designed to distinguish the MiTFL1 genes. The MiActin1 gene of mango was used as the internal reference gene [46]. The PCR mixture contained $10 \mu \mathrm{l}$ of SYBR Premix Ex Taq II (Takara), $1 \mu \mathrm{l}$ of cDNA (100 ng/ $\mu \mathrm{l}), 0.5 \mu \mathrm{l}(10 \mu \mathrm{M})$ of the upstream and downstream primers, $0.8 \mu \mathrm{l}$ of ROX Reference Dye II, and sterile water to obtain a total volume of $20 \mu \mathrm{l}$. The PCR amplification conditions included $30 \mathrm{~s}$ at $95^{\circ} \mathrm{C}$; 40 cycles of $95^{\circ} \mathrm{C}$ for $5 \mathrm{~s}, 60^{\circ} \mathrm{C}$ for $34 \mathrm{~s}$, and $95^{\circ} \mathrm{C}$ for $15 \mathrm{~s} ; 60^{\circ} \mathrm{C}$ for $1 \mathrm{~min}$; and $95^{\circ} \mathrm{C}$ for $15 \mathrm{~s}$. The relative transcript abundances were estimated using the $2^{-\Delta \Delta C t}$ method [47]. The analysis of each sample included three biological replicates.

\section{Subcellular localization of MiTFL1 proteins}

The complete coding sequences of MiTFL1 genes without terminator codons were constructed into the P1300GFP vector between the $X b a \mathrm{I}$ and $B a m H I$ restriction enzyme cleavage sites. The constructed vectors were transformed into Agrobacterium tumefaciens EHA105. The GFP fusion vectors and empty vector were subsequently transformed into onion epidermal cells via A. tumefaciens EHA105. 4',6-Diamidino-2-phenylindole (DAPI) was used to visualize the nucleus. Images were captured using a high-resolution laser confocal microscope (TCSSP8MP; Leica, Germany).

\section{Plasmid construction and genetic transformation}

The MiTFL1-overexpressing (OE) vectors were constructed by cloning the genes into the pBI121 binary vector using CaMV $35 \mathrm{~S}$ as the promoter between the $X b a \mathrm{I}$ and $X m a \mathrm{I}$ restriction enzyme cleavage sites. The overexpression plasmids were transferred into the $A$. tumefaciens strain EHA105. The overexpression vectors and empty vector were subsequently transformed into WT A. thaliana using the floral-dip method [48]. The transgenic seeds were selected on 1/2 MS medium containing $50 \mathrm{mg} / \mathrm{l} \mathrm{kanamycin} \mathrm{and} \mathrm{confirmed} \mathrm{by} \mathrm{genomic}$ PCR. The specific primers MiTFL1-1u/d, MiTFL1-2u/d, MiTFL1-3u/d and MiTFL1-4u/d were used to detect whether transformation of the MiTFL1 genes was successful. Homozygous T3 transgenic plants were used for subsequent experiments.

\section{Phenotypic analyses}

Wild-type and empty vector-transformed Arabidopsis plants were used as controls. Several phenotypic indexes, including the bolting time, flowering time, time from bolting to flowering, and rosette leaves, were measured. To detect the expression levels of the MiTFL1 genes and some flowering-related genes in transgenic and control plants, 30-day-old seedlings of both transgenic and WT Arabidopsis plants were collected for total RNA extraction. Total RNA was extracted, and first-strand cDNA was synthesized as described above. Semiquantitative 
RT-PCR was performed to determine the expression levels of the MiTFL1 genes in the transgenic and control lines. The PCR amplification conditions comprised an initial denaturation step of $2 \mathrm{~min}$ at $95^{\circ} \mathrm{C} ; 30$ cycles of $95^{\circ} \mathrm{C}$ for $30 \mathrm{~s}, 56^{\circ} \mathrm{C}$ for $30 \mathrm{~s}$, and $72{ }^{\circ} \mathrm{C}$ for $30 \mathrm{~s}$; and a final extension at $72{ }^{\circ} \mathrm{C}$ for $5 \mathrm{~min}$. The PCR products were electrophoretically separated on a $1.8 \%$ agarose gel. The expression levels of some endogenous floweringrelated genes in transgenic and control Arabidopsis lines were detected by qRT-PCR using the reaction system and conditions described above. Arabidopsis AtACTIN2 was used as the internal reference gene for qRT-PCR analysis. All the primers used in this study are listed in Table S1.

\section{Proteins interacting with the MiTFL1 proteins}

A cDNA library from $M$. indica L. cv. SijiMi leaves and flowering organs was constructed using the Yeast TwoHybrid Library Construction Kit (Clontech, Dalian, China). $\mathrm{Y} 2 \mathrm{H}$ assays were performed according to the Yeastmaker $^{\mathrm{Tm}}$ Yeast Transformation System 2 protocol (Clontech). The complete coding sequences of the MiTFL1 genes were inserted into the pGBKT7 vector between the NdeI and $E c o R$ I restriction enzyme cleavage sites. The pGBKT7-bait plasmid was transformed into competent $\mathrm{Y} 2 \mathrm{H}$ Gold yeast cells, which were diluted $10^{-1}$ and $10^{-2}$ and coated on SDO/-Trp, SDO/-Trp/Xalpha-Gal and SDO/-Trp/X-Alpha-Gal/AbA media. The transcriptional activity and toxicity were verified using this method.

The interacting proteins were identified by screening a DNA library on QDO/-Trp/-Leu/-His/-Ade culture medium. The plasmids of the interacting proteins were extracted and used for further verification of the actual interactions. $\mathrm{Y} 2 \mathrm{H}$ Gold yeast cells containing the pGBKT7-bait plasmid and Y187 yeast cells containing the candidate prey were mixed and cultured in liquid medium containing $2 \times \mathrm{YPDA}$ at $30^{\circ} \mathrm{C}$ and $200 \mathrm{rpm}$ for $20-24 \mathrm{~h}$. The mixture was then coated on DDO/-Trp/ $-\mathrm{Leu} / \mathrm{X}$ and QDO/X/A media and cultured for 3-5 days. Blue colonies on the media indicated a positive interaction. The AbA concentration was $500 \mu \mathrm{g} / \mathrm{ml}$, and the $\mathrm{X}$ - $\alpha$-gal concentration was $200 \mathrm{ng} / \mathrm{ml}$. Y2H Gold (pGBKT7-53) and Y187 (pGADT7-T) served as positive controls, and Y2H Gold (pGBKT7-LAM) and Y187 (pGADT7-T) were used as negative controls.

\section{Statistical analysis}

SPSS 19.0 statistical software (SPSS Inc., Chicago, IL, United States) was used for the statistical analyses.

\section{Abbreviations}

CTAB: Hexadecyltrimethylammonium bromide; qRT-PCR: Quantitative reverse transcription-polymerase chain reaction; DAPI: 6-diamidino-2-phenylindole; X-
Alpha-Gal: 5-bromo-4-chloro-3-indoxyl-a-D-galactopyranoside; AbA: Aureobasidin A

\section{Supplementary Information}

The online version contains supplementary material available at https://doi. org/10.1186/s12870-021-03199-9.

\author{
Additional file 1 : Supplementary Table 1. Four TFL1 interacting \\ protein through yeast two hybrid.
}

Additional file $\mathbf{2}$ : Supplementary Table $\mathbf{2}$. Primers used in this study. Additional file $\mathbf{3}$ : Supplement Figure 1. Source data for Figs. 5 and 6. (a) The red frame indicates the source data in Fig. S1a displayed for Fig. 5a-a1. (b) The source data in Fig. S1b displayed for Fig. 5b-b1. (c) The source data in Fig. S1c displayed for Fig. 6a-a1. (d) The source data in Fig. S1d displayed for Fig. 6b-b1.

Additional file 4 : Supplement Figure 2. The autoactivation and toxicity of pGBKT7-MiTFL1s vector, concentrations of $10^{-1}$. Yeast bait expression vectors of MiTFL1-1, MiTFL1-2, MiTFL1-3 and MiTFL1-4 were constructed by double enzyme digestion method, and transferred into $\mathrm{Y} 2 \mathrm{H}$ Gold yeast, which were cultured in SDO/-Trp, SDO/X and SDO/X/A medium. Y2H Gold (pGBKT7-53) served as positive controls, and Y2H Gold (pGBKT7-lam) were used as negative controls. The results showed that the four PGBKT7-MiTFL1s had no autoactivation and toxicity.

Additional file 5 : Supplement Figure 3. Comparison of CDNA sequences of four MiTFL1 genes in two cultivars of 'Alphonso' and 'SiJiMi'. (A) The comparative similarity between the two cultivars of MiTFL1-1 gene was $99.4 \%$. (B) The comparative similarity between the two cultivars of MiTFL 1-2 gene was $100.0 \%$. (C) The comparative similarity between the two cultivars of MiTFL1-3 gene was 98.5\%. (D) The comparative similarity between the two cultivars of MiTFL 1-4 gene was 98.3\%.

Additional file $\mathbf{6}$ : Supplement Figure 4. The primer design site of MiTFL1s gene was used for qRT-PCR. CDNA sequence comparison of the four genes, where the yellow shaded part represents the start codon and the red shaded part represents the stop codon. The red sequence represents the upstream primer sequence and the blue sequence represents the downstream primer sequence. The black part indicates a similarity of $100 \%$.

\section{Acknowledgments}

Not applicable.

\section{Authors' contributions}

$\mathrm{CL}$ and $\mathrm{XHH}$ designed and procured funding for this study. $\mathrm{YHW}$ performed the experiments. HXY, XM, YF, ZYF, XJX, and YL helped with the experiments and data analysis. YHW and $\mathrm{CL}$ wrote the manuscript. All the authors have read and approved the manuscript.

\section{Funding}

This research was supported by grants from the National Natural Science Foundation of China (31860541 and 31660561), Science and Technology Major Projects of Guangxi (GuiKeAA17204026 and GuiKe AA17204097), State Key Laboratory for Conservation and Utilization of Subtropical Agrobioresources (SKLCUSA-c201901) and Innovation Team of Guangxi Mango Industry Project (nycytxgxcxtd- 07-02). The funders had no role in the design of the study; collection, analysis, and interpretation of the data; and writing of the manuscript but provided financial support.

\section{Availability of data and materials}

All the data generated or analyzed during this study are included in this published article and its supplementary information files. The datasets generated in this study are available in GenBank (http://www.ncbi.nlm.nih. gov/Genbank), and the accession numbers are as follows: AtTFL1 (NP_196004.1), CsTFL1 (NP_001275848), DITFL1 (AHY24028.1), JrTFL1 (XP_018811176.1), MdTFL1 (NP_001280887.1), PpTFL1 (NP_001289244.1), VvTFL1A (NP_001267929.1), MdCEN (NP_001280940.1), PvCEN protein 1 (XP_031269481.1), TCCEN (XP_017973069.1), HmTFL1 (MF374628.1), GmTFL1.3 (FJ573238.1), FCTFL1-2 (AB746842.1), CCTFL1 (XP_006430226.1), CITFL1 (AWW25018.1), FCTFL1 (BAX00857.1), NsTFL1 (XP_009766168.1), PmTFL1 
(AEO72021.1), PyTFL1 (AEO72023.1), VVTFL1C (NP_001267933.1), ZjTFL1 (XP_015898753.1), AcFT (AJA40932.1), AtFT (BAA77838.1), EdFT (AMB72867.1), MiFT (AGA19021.1), VvFT (NP_001267907.1), AtMFT (OAP13671.1), CIMFT (AWW25016.1), DIMFT (AUG98253.1), and VvMFT (NP_001267935.1).

\section{Declarations}

\section{Ethics approval and consent to participate}

All the materials of this project are given by Guangxi University (Nanning, China). The experimental research on plants performed in this study complies with institutional, national and international guidelines.

\section{Consent for publication}

Not applicable.

\section{Competing interests}

The authors declare that they have no competing interests.

\section{Received: 7 February 2021 Accepted: 31 August 2021}

Published online: 07 September 2021

\section{References}

1. Larsson AS, Landberg K, Meeks-Wagner DR. The TERMINAL FLOWER2 (TFL2) gene controls the reproductive transition and meristem identity in Arabidopsis thaliana. Genetics. 1998;149(2):597-605. https://doi.org/10.1093/ genetics/149.2.597.

2. Prudencio AS, Hoeberichts FA, Dicenta F, Martínez-Gómez P, Sánchez-Pérez R. Identification of early and late flowering time candidate genes in endodormant and ecodormant almond flower buds. Tree Physiol. 2020. https://doi.org/10.1093/treephys/tpaa151.

3. He YH. Chromatin regulation of flowering. Trends Plant Sci. 2012;17(9):55662. https://doi.org/10.1016/j.tplants.2012.05.001.

4. Zhao W, Gu R, Che G, Cheng Z, Zhang X. CsTFL16 may regulate the flowering time and inflorescence architecture in cucumber (Cucumis sativus L.). Biochem Biophys Res Commun. 2018:499(2):307-13.

5. Luccioni L, Krzymuski M, Sanchezlamas M, Karayekov E, Cerdán PD, Casal JJ. CONSTANS delays Arabidopsis flowering under short days. Plant J. 2018;97(5): 923-32. https://doi.org/10.1111/tpj.14171.

6. Wells RS, Adal AM, Bauer L, Najafianashrafi E, Mahmoud SS. Cloning and functional characterization of a floral repressor gene from Lavandula angustifolia. Planta. 2020;251(2):41. https://doi.org/10.1007/s00425-01903333-w.

7. Sheldon CC, Rouse DT, Finnegan EJ, Peacock WJ, Dennis ES. The molecular basis of vernalization: the central role of FLOWERING LOCUS C (FLC). ProC Natl Acad Sci U S A. 2000;97(7):3753-8. https://doi.org/10.1073/pnas.97.7.3 753.

8. Won SY, Jung JA, Kim JS. Genome-wide analysis of the MADS-box gene family in Chrysanthemum. Comput Biol Chem. 2021;90:107424. https://doi. org/10.1016/j.compbiolchem.2020.107424.

9. Ream TS, Woods DP, Amasino RM. The molecular basis of vernalization in different plant groups. Proc Natl Acad Sci U S A. 2011;77:105-15.

10. Sharma B, Batz TA, Kaundal R, Kramer EM, Larson RB. Developmental and molecular changes underlying the vernalization-induced transition to flowering in Aquilegia coerulea (James). Genes. 2019;10(10):734. https://doi. org/10.3390/genes10100734.

11. Shannon S, Meeks-Wagner DR. A mutation in the Arabidopsis TFL1 gene affects inflorescence meristem development. Plant Cell. 1991;3(9):877-92. https://doi.org/10.2307/3869152.

12. Carmona MJ, Calonje M, Martínez-Zapater JM. The FT/TFL1 gene family in grapevine. Plant Mol Biol. 2007;63(5):637-50. https://doi.org/10.1007/s11103006-9113-z.

13. Yang ZL, Chen L, Kohnen MV, Xiong B, Zhen X, Liao J, et al. Identification and characterization of the PEBP family genes in Moso Bamboo ( Phyllostachys heterocycla ). Sci Rep. 2019;9:14998.

14. Liu X, Zhang J, Xie DY, Franks RG, Xiang QJ. Functional characterization of terminal flower 1 homolog in Cornus canadensis by genetic transformation. Plant Cell Rep. 2019;38(3):333-43. https://doi.org/10.1007/s00299-019-023 69-2.

15. Bradley D, Ratcliffe O, Vincent C, Carpenter R, Coen E. Inflorescence commitment and architecture in Arabidopsis. Science. 1997:275(5296):80-3. https://doi.org/10.1126/science.275.5296.80.
16. Esumi T, Kitamura Y, Hagihara C, Yamane H, Tao R. Identification of a TFL1 ortholog in Japanese apricot (Prunus mume Sieb. et Zucc.). Sci Hortic. 2010; 125(4):608-16. https://doi.org/10.1016/j.scienta.2010.05.016.

17. Moraes TS, Dornelas MC, Martinelli AP. FT/TFL1: calibrating plant architecture. Front Plant Sci. 2019;10:97. https://doi.org/10.3389/fpls.2019. 00097.

18. Périlleux C, Bouché F, Randoux M, Orman-Ligeza B. Turning meristems into fortresses. Trends Plant Sci. 2019;24(5):431-42. https://doi.org/10.1016/j.tpla nts.2019.02.004

19. Wickland DP, Hanzawa Y. The FLOWERING LOCUS T/TERMINAL FLOWER 1 gene family: functional evolution and molecular mechanisms. Mol Plant. 2015;8(7):983-97. https://doi.org/10.1016/j.molp.2015.01.007.

20. Conti L, Bradley D. TERMINAL FLOWER 1 is a mobile signal controlling Arabidopsis architecture. Plant Cell. 2007;19(3):767-78. https://doi.org/10.11 05/tpc.106.049767.

21. Flachowsky H, Peil A, Sopanen T, Elo A, Hanke V. Overexpression of BPMADS4 from silver birch (Betula pendula Roth.) induces early-flowering in apple (Malus aldomestica Borkh.). Plant Breed. 2007;126(2):137-45. https:// doi.org/10.1111/j.1439-0523.2007.01344.x.

22. Freiman A, Shlizerman L, Golobovitch S, Yablovitz Z, Korchinsky R, Cohen Y, et al. Development of a transgenic early flowering pear (Pyrus communis L) genotype by RNAi silencing of PCTFL1-1 and PCTFL1-2. Planta. 2012;235(6): 1239-51. https://doi.org/10.1007/s00425-011-1571-0.

23. Luo C, Yu HX, Fan Y, Zhang XJ, He XH. Research advance on the flowering mechanism of mango. Acta Hortic. 2019;1244(2):17-22. https://doi.org/10.1 7660/ActaHortic.2019.1244.2.

24. Wang P, Luo YF, Huang JF, Gao SH, Zhu GP, Dang ZG, et al. The genome evolution and domestication of tropical fruit mango. Genom Biol. 2020; 26(1):60. https://doi.org/10.1186/s13059-020-01959-8.

25. Wei JY, Liu DB, Liu GY, Tang J, Chen YY. Molecular cloning, characterization, and expression of MiSOC1: a homolog of the flowering gene SUPPRESSOR OF OVEREXPRESSION OF CONSTANS1 from mango (Mangifera indica $\mathrm{L}$ ). Front Plant Sci. 2016;7:1758. https://doi.org/10.3389/fpls.2016.01758.

26. Yu HX, Luo C, Fan Y, Zhang XJ, Huang F, Li M, et al. Isolation and characterization of two APETALA1-Like genes from mango (Mangifera indica L.). Sci Hortic (Amsterdam, Neth.). 2020;259:108814.

27. Fan ZY, He XH, Fan Y, Yu HX, Wang YH, Xie XJ, et al. Isolation and functional characterization of three MiFTs genes from mango. Plant Physiol Bioch. 2020;155:169-76. https://doi.org/10.1016/j.plaphy.2020.07.009.

28. Liu Y, Luo C, Zhang XJ, Lu XX, Yu HX, Xie XJ, et al. Overexpression of the mango MiCO gene delayed fowering time in transgenic Arabidopsis. Plant Cell Tissue Organ Cult. 2020;143(1):219-28. https://doi.org/10.1007/s11240020-01894-3.

29. Hanzawa Y, Money T, Bradley D. A single amino acid converts a repressor to an activator of flowering. Proc Natl Acad Sci U S A. 2005;102(21):7748-53. https://doi.org/10.1073/pnas.0500932102.

30. Liu B, Watanabe S, Uchiyama T, Kong F, Kanazawa A, Xia Z, et al. The soybean stem growth habit gene Dt1 is an ortholog of Arabidopsis TERMINAL FLOWER 1. Plant Physiol. 2010;153(1):198-210. https://doi.org/1 0.1104/pp.109.150607

31. Jiang $Y Y$, Zhu YM, Zhang $L$, Su WB, Peng JR, Yang XH, et al. EjTFL1 genes promote growth but inhibit flower bud differentiation in loquat. Front Plant Sci. 2020;11:576. https://doi.org/10.3389/fpls.2020.00576.

32. Wu L, Li F, Deng Q, Zhang S, Liu G. Identification and characterization of the FLOWERING LOCUS T/TERMINAL FLOWER 1 gene family in petunia. DNA Cell Biol. 2019;38(9):982-95. https://doi.org/10.1089/dna.2019.4720.

33. Zhang $X$, Wang $C$, Pang $C$, Wei $H$, Wang $H$, Song $M$, et al. Characterization and functional analysis of PEBP family genes in upland cotton (Gossypium hirsutum L.). PLoS ONE. 2016;11(8):e0161080.

34. Kotoda N, Iwanami H, Takahashi S, Abe K. Antisense expression of MdTFL1, a TFL 1-like gene, reduces the juvenile phase in apple. J Am Soc Hortic Sci. 2006:131(1):74-81. https://doi.org/10.21273/JASHS.131.1.74

35. Vyavahare SN, Krishna B, Joshi SS, Chaudhari RS, Sane PV. Characterization of mango flowering Locus T (FT) and TERMINAL flower 1 (TFL1) gene. J Am Soc Hortic Sci. 2017: 1183(1183):113-24. https:/doi.org/10.17660/ActaHortic.2017.1183.16

36. Pillitteri $\mathrm{L}$, Lovatt CJ, Walling LL. Isolation and characterization of a TERMINAL FLOWER homolog and its correlation with juvenility in citrus. Plant Physiol. 2004;135(3):1540-51. https://doi.org/10.1104/pp.103.036178.

37. Chen $Y$, Jiang $P$, Thammannagowda S, Liang H, Wilde HD. Characterization of peach TFL 1 and comparison with FT/TFL1 gene families of the rosaceae. J Am Soc Hortic Sci. 2013;138(1):12-7. https://doi.org/10.21273/JASHS.138.1.12 
38. Esumi T, Tao R, Yonemori K. Isolation of LEAFY and TERMINAL FLOWER 1 homologues from six fruit tree species in the subfamily maloideae of the rosaceae. Sex Plant Reprod. 2005;17(6):277-87. https://doi.org/10.1007/s004 97-004-0239-3.

39. Bi Z, Tahir AT, Huang H, Hua Y. Cloning and functional analysis of five TERMINAL FLOWER 1/CENTRORADIALIS-like genes from Hevea brasiliensis. Physiol Plant. 2019;166(2):612-27.

40. Kotoda N, Wada M. MdTFL1, a TFL1 -like gene of apple, retards the transition from the vegetative to reproductive phase in transgenic Arabidopsis. Plant Sci. 2005;168(1):95-104. https://doi.org/10.1016/j.plantsci.2004.07.024.

41. Wang Y, Pijut PM. Isolation and characterization of a TERMINAL FLOWER 1 homolog from Prunus serotina Ehrh. Tree Physiol. 2013;33(8):855-65. https:// doi.org/10.1093/treephys/tpt051.

42. Gao Y, Gao Y, Wu Z, Bu X, Fan M, Zhang Q. Characterization of TEMINAL FLOWER 1 homologs CmTFLIC gene from Chrysanthemum morifolium. Plant Mol Biol. 2019;99(6):587-601. https://doi.org/10.1007/s11103-019-00838-6.

43. Liu Y, Gao Y, Yuan L, Zhang Q. Functional characterization and spatial interaction of TERMINAL FLOWER 1 in Hemerocallis. Sci Hortic. 2019;253:15462. https://doi.org/10.1016/j.scienta.2019.03.036.

44. Miho KS, Rie Kl, Chiaki OT, Chojiro K, Misa NF, Izuru O, et al. TFL1-like proteins in rice antagonize rice FT-like protein in inflorescence development by competition for complex formation with 14-3-3 and FD. Plant Cell Physiol. 2018;59(3):458-68. https://doi.org/10.1093/pcp/pcy021.

45. Niu X, Guan YX, Chen SK, Li HF. Genome-wide analysis of basic helix-loophelix (bHLH) transcription factors in Brachypodium distachyon. BMC Genomics. 2017;18(1):619. https://doi.org/10.1186/s12864-017-4044-4.

46. Luo C, He XH, Chen H, Hu Y, Ou SJ. Molecular cloning and expression analysis of four actin genes (MiACT) from mango. Biol Plant. 2013;57(2):23844. https://doi.org/10.1007/s10535-012-0278-9.

47. Livak KJ, Schmittgen TD. Analysis of relative gene expression data using real-time quantitative $P C R$, and the $2^{-\Delta \Delta C T}$ method. Methods. 2001;25(4): 402-8.

48. Clough SJ, Bent AF. Floral dip: a simplifed method for Agrobacteriummediated transformation of Arabidopsis thaliana. Plant J. 1998;16(6):735-43. https://doi.org/10.1046/j.1365-313x.1998.00343.x.

\section{Publisher's Note}

Springer Nature remains neutral with regard to jurisdictional claims in published maps and institutional affiliations.

Ready to submit your research? Choose BMC and benefit from:

- fast, convenient online submission

- thorough peer review by experienced researchers in your field

- rapid publication on acceptance

- support for research data, including large and complex data types

- gold Open Access which fosters wider collaboration and increased citations

- maximum visibility for your research: over $100 \mathrm{M}$ website views per year

At BMC, research is always in progress.

Learn more biomedcentral.com/submissions 